\title{
An Old Relict Glacier Body Preserved in Permafrost Environment: The Foscagno Rock Glacier Ice Core (Upper Valtellina, Italian Central Alps)
}

\author{
Mauro Guglielmin,* \\ Marina Camusso, $\dagger$ \\ Stefano Polesello, $\dagger$ and \\ Sara Valsecchi $\dagger$ \\ *Insubria University, Via J. H. Dunant, \\ 321100 Varese, Italy. \\ mauro.guglielmin@uninsubria.it \\ $\dagger$ Water Research Institute, CNR, Via della \\ Mornera 25, 20047 Brugherio, Italy.
}

\begin{abstract}
This paper shows the results of chemical and crystallographic analyses carried out on a core drilled within the frontal part of the Foscagno rock glacier in the Italian Alps. We use 58 vertical thin sections spaced along the massive ice core, found between depths of 2.5 and $7.65 \mathrm{~m}$, to describe the ice fabric of the core. We also discuss the results of chemical analyses of more than 50 samples. The lower part of the massive ice core between 4 and 7.65 $\mathrm{m}$ shows a mean crystal size of $1.5 \mathrm{~cm}$ and a crystal shape predominantly elongated along the horizontal plane with c-axes. These characteristics are similar to those of firn ice. In contrast, the upper core between 2.5 and $4 \mathrm{~m}$ displays vertical elongation of large bubbles, indicating superimposed ice and the influence of melting and refreezing processes. The presence of a seasonal signal in sulfate distribution and the strong correlation between sodium and chloride in the lower part of the core confirm cold firnification without appreciable phase changes. This well-preserved glacier ice body is probably younger than $2200 \pm 60 \mathrm{yr}$ B.P., a minimum age for the rock glacier as indicated by the ${ }^{14} \mathrm{C}$ age of a buried paleosoil, although the possibility that it may be older age cannot be excluded. The glacier ice body seems to be a relict of a former glacier preserved within a larger permafrost body that characterizes almost all of the rock glacier and also occurs beneath the massive ice. This finding points out that different types of ice can be preserved within a single rock glacier, reflecting a complex geological and paleoclimatic history.
\end{abstract}

\section{Introduction}

Few boreholes have been drilled in rock glaciers and, in most cases, without coring. To our knowledge, in only two cases, Murtel I (Baltensperger et al., 1990; Haeberli, 1985; Haeberli et al., 1999) and Galena Creek (Clark et al., 1996; Potter, 1972; Steig et al., 1998), has ice been studied in detail to determine its origin.

The question of the origin of the ice within rock glaciers is debated. Some authors have considered the ice that crops out in the Gruben rock glacier (Whalley, 1974) or that found in the tunnel cut through the Hurricane Basin rock glacier (Brown, 1925) to be glacier ice; in both cases the same ice has been interpreted by other authors (Haeberli et al., 1988; Barsch, 1987) as ground ice formed under permafrost conditions, polygenetic in origin.

In this paper we analyze some ice properties of a buried ice body within a rock glacier, the Foscagno rock glacier, in order to obtain information concerning its formation.

\section{Study Site}

Foscagno Valley is a tributary of Viola Bormina Valley, from which it is separated by the Mt. Forcellina-Mt. Sattaron ridge (Fig. 1). The geomorphologic history of the valley and the paleoclimatic reconstruction during the Late Glacial are already known (Calderoni et al., 1993, 1998; Guglielmin, 1997; Guglielmin and Tellini, 1994). Less clear is the situation during the Holocene because, as in many other alpine valleys, evidence of glacial events from that time period is limited by the development of mass wasting deposits and rock glaciers. For example, the Little Ice Age (LIA) is not well displayed in Foscagno Valley, although Guglielmin et al. (2001) suggested that the maximum LIA extent reached $2650 \mathrm{~m}$ a.s.l. in the Forcellina cirque, where a small ice body not covered by debris was present on the northern slope until 1932.

The Forcellina cirque is occupied by the Foscagno rock glacier, the most-studied rock glacier of the Italian Alps (Guglielmin, 1989, 1997; Calderoni et al., 1993, 1998; Guglielmin et al., 1994; Hauck et al., 2001). ${ }^{14} \mathrm{C}$ dating of paleosoils, buried under the left lobe of the active part of the Foscagno rock glacier and under the front of its inactive part, gives respective uncalibrated ages of $2200 \pm 60 \mathrm{yr}$ and $2700 \pm 70 \mathrm{yr}$ B.P. (Calderoni et al., 1998).

The distribution of permafrost in the valley, and above all in the Foscagno rock glacier, is fairly well known (Guglielmin and Tellini, 1994; Guglielmin et al., 1994, 2001; Guglielmin, 1997; Hauck et al., 2001). The permafrost occurrence is patchy, even within the Foscagno rock glacier, as indicated by the high variability of ground resistivity (Guglielmin et al., 1994). The thickness of the active layer (or superficial unfrozen material; Guglielmin et al., 1994), ranges from 1.2 to $1.5 \mathrm{~m}$ to almost $10 \mathrm{~m}$ from the north-facing slope to the southeastfacing one.

The borehole location was chosen by taking into account the previous geophysical investigations (Guglielmin et al., 1994; Guglielmin, 1997). Drilling was carried out in the frontal part of the right lobe of Foscagno active rock glacier (Fig. 2) where the highest resistivity values (between 500 and $1000 \mathrm{k} \Omega \mathrm{m}$ ) were measured and where the active layer was about $2 \mathrm{~m}$ thick.

\section{Methods}

The Foscagno rock glacier borehole was drilled between 18 and 24 June 1998 at $2510 \mathrm{~m}$ a.s.l. and reached a depth of $24 \mathrm{~m}$. On 19 June 1998 the frost table was at $-2.3 \mathrm{~m}$; the basal cryopeg was crossed at a depth of about $14.5 \mathrm{~m}$; and the weathered underlying bedrock was reached at $-23.5 \mathrm{~m}$. The upper $2.5 \mathrm{~m}$ and the lower $9.5 \mathrm{~m}$ of the Foscagno rock 


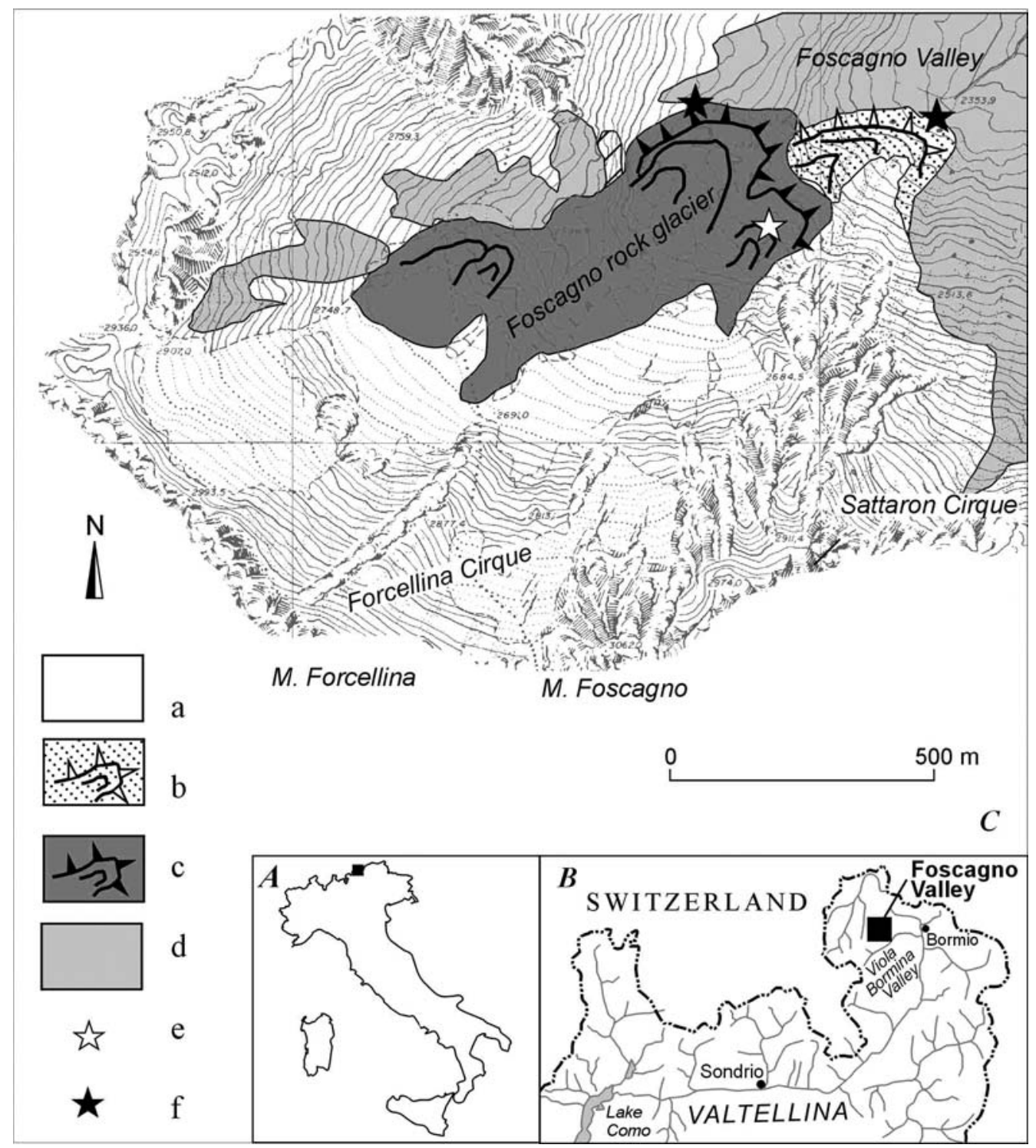

FIGURE 1. Geographical and geomorphologic location of the Foscagno Rock Glacier: (a) undifferentiated scree slopes and bedrock outcrops; (b) inactive rock glacier; (c) active rock glacier; (d) morainic deposits (Pleistocene age); (e) borehole location; $(f){ }^{14} \mathrm{C}$ ages (from Guglielmin et al., 2001, modified).

glacier borehole were drilled with a hammer drill. Coring was performed in the middle part of the borehole (between 2.5 and 14.5 m) with a diamond drill head and a triple sampler (T121) using compressed and refrigerated air as well as liquid. The stratigraphy of the borehole is shown in Figure 3 (reprinted from Guglielmin et al., 2001).

\section{CRYSTALLOGRAPHIC ANALYSIS}

The ice core retrieved was cut into samples about $50 \mathrm{~cm}$ long, sealed in polyethylene bags after a macroscopic visual description, and stored in a cold room at $-25^{\circ} \mathrm{C}$. The upper core between 250 and $400 \mathrm{~cm}$ depth was so highly fractured that no single chip was suitable for cutting a thin section. Fifty-eight thin vertical sections $(0.8 \mathrm{~mm}$ thick) between 400 and $765 \mathrm{~cm}$ depth were cut in the cold room of Milan II University (Teruzzi, 2000). Below $755 \mathrm{~cm}$, the large amount of sediment did not allow preparation of thin sections. All sections were photographed with normal and polarized light using different magnifications. For each thin section, optical $\mathrm{C}$-axes were determined according to the procedure reported in Langway (1958), and the results were plotted on Schmidt (equiareal, lower hemisphere) stereograms.
We used two different methods to describe crystal size. First, the method of the mean intercept (L) (Thorsteinsson et al., 1995) which entails counting the number of crystals that cross a line drawn on the thin section and dividing the total length of the line by the number obtained. The second method entails the direct measurement (DM) of the crystals with $\mathrm{L}$ greater than $5 \mathrm{~mm}$. Both methods were applied along a horizontal plane $(\mathrm{X})$ and along a vertical plane $(\mathrm{Z})$.

The number of gas bubbles was also counted. For bubbles greater than $1 \mathrm{~mm}$, area, diameters, and shapes (circular, elongated, or pearshaped) were estimated by using comparison masks. Furthermore, the crystals in every thin section were classified according to their configurations (sharp, rounded, or subrounded) and contacts with other ones (linear-regular or composed-irregular).

\section{CHEMICAL ANALYSES}

Chemical analyses were carried out on 6 fragments of the upper core, corresponding to a sample about every $20-30 \mathrm{~cm}$. From 400 to 755 $\mathrm{cm}, 44$ sections ( $3 \mathrm{~cm}$ thick) were analyzed, corresponding to a sample every 5-9 cm. The ionic content of about 20 samples from the lower 


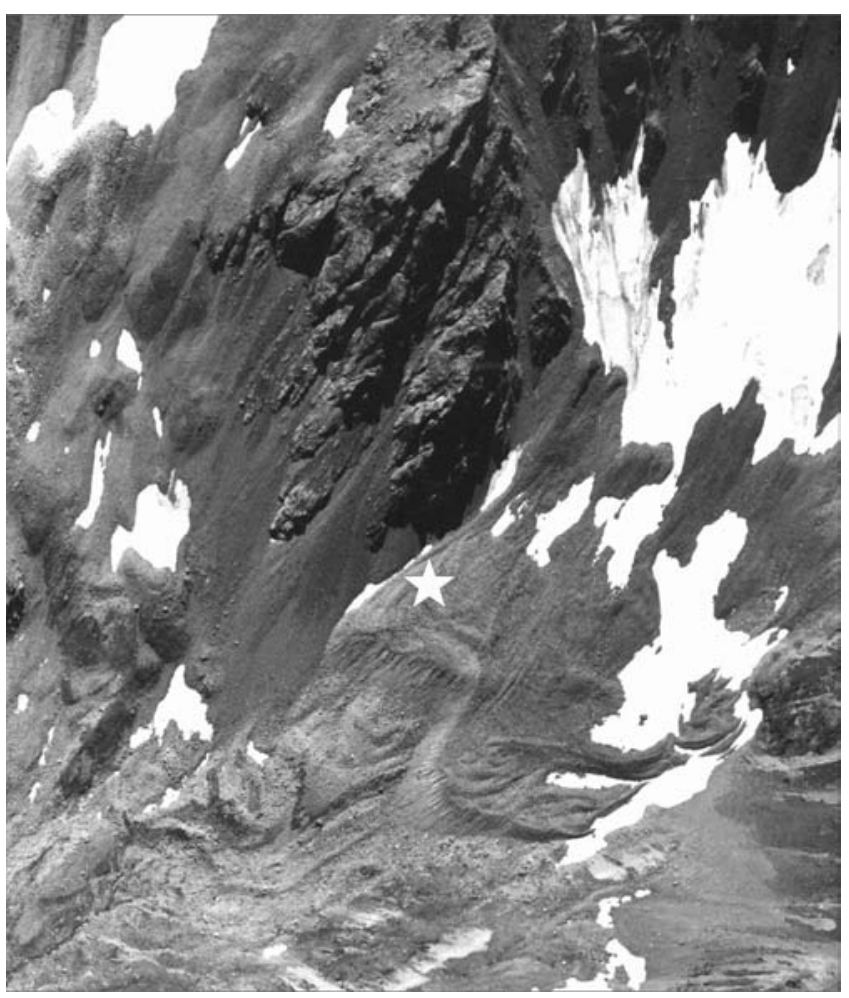

FIGURE 2. Aerial view of Foscagno Valley and rock glacier. The white star indicates the location of the borehole.

core (a sample about every $30 \mathrm{~cm}$ from 842 to $1450 \mathrm{~cm}$ ) was also determined.

Ice samples were melted under a laminar flow hood and filtered on $0.45-\mu \mathrm{m}$ mixed cellulose ester membrane filters (filter HA Millipore, MA, U.S.A.) before inorganic ion analyses.

Cations $\left(\mathrm{Na}^{+}, \mathrm{NH}_{4}^{+}, \mathrm{K}^{+}, \mathrm{Mg}^{2+}\right.$ and $\left.\mathrm{Ca}^{2+}\right)$ were separated on an IonPac CS12 column ( $20 \mathrm{mM}$ methanesulfonic acid at $1.0 \mathrm{~mL} \mathrm{~min}^{-1}$ as eluent), with an IonPac CG12 precolumn, by a Dionex 4500i (Sunnyvale, CA, U.S.A.) ion chromatograph equipped with a CSRSII cation self-regenerant suppressor and a CDM-II conductivity detector. Anions $\left(\mathrm{Cl}^{-}, \mathrm{NO}_{3}{ }^{-}\right.$, and $\left.\mathrm{SO}_{4}{ }^{2-}\right)$ were separated on an IonPac AS4A column (1.8 mM Na $\left.2 \mathrm{CO}_{3} / 1.7 \mathrm{mM} \mathrm{NaHCO}{ }_{3}, 2 \mathrm{~mL} \mathrm{~min}^{-1}\right)$, with an IonPac AG4A precolumn, by a Dionex 2000i ion chromatograph equipped with an ASRS-ultra $(4 \mathrm{~mm})$ anion self-regenerant suppressor and a CDM-II conductivity detector. Ten $\mathrm{mL}$ of melted ice samples were on-line preconcentrated with IonPac TAC-2 and IonPac TCC-LP1 before ion chromatography analysis. The ion chromatographic detection limits of the preconcentration method were $0.010 \mu \mathrm{eq} \mathrm{L}^{-1}$ for each ion. Dynamic range for anions and cations was covered by two different linear weighted calibration curves, one from 0.025 to $1 \mu \mathrm{eq}^{-1}$ and the other from 1 to $10 \mu \mathrm{eqL} \mathrm{L}^{-1}$.

Accuracy was established by NBS (2694-I) certified material. Reproducibility was estimated by standard replicate coefficient of variation, which ranges from $30 \%$ at detection limits to $2-3 \%$ at 10 $\mu \mathrm{eqL} \mathrm{L}^{-1}$.

\section{Results and Discussion}

\section{ICE FABRIC}

The massive ice, cored between 250 and $765 \mathrm{~cm}$ depth, can be divided into two parts according to its macroscopic characteristics. The upper core (250-400 cm deep), composed of white ice and very rich in elongated bubbles $(0.5-2 \mathrm{~mm})$, was almost completely crushed because
Depth (m) 0.00

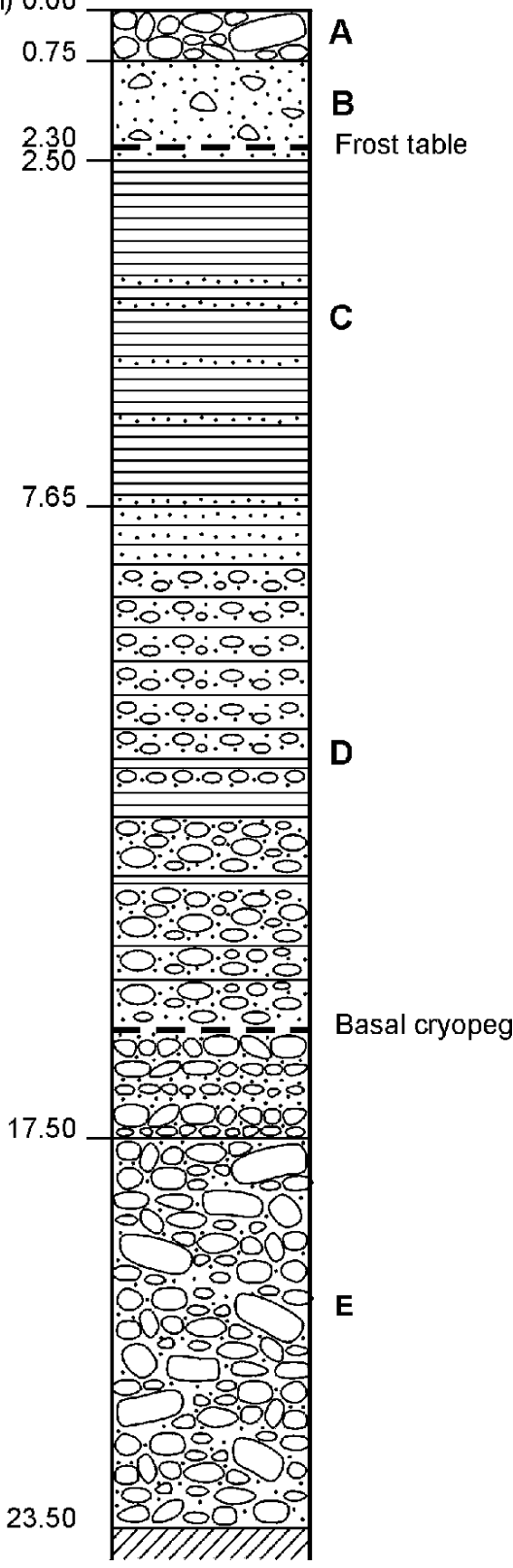

FIGURE 3. Stratigraphy of the borehole: (a) landslide deposit; (b) ablation till (Holocene); (c) massive ice body; (d) alternation of ice layers and ice-cemented debris flows sediments; (e) unfrozen ablation till (?). The bottom of the borehole is of phyllitic bedrock.

of a high fracture frequency (ice type A; Fig. 4a). The middle core (401$765 \mathrm{~cm}$ ) showed layers of almost transparent ice, with some undeformed small bubbles $(0.3-0.5 \mathrm{~mm})$, abundant rock inclusions and subhorizontal debris bands (ice type B; Fig. 4b), and layers of foliated ice with large tabular crystals alternating with thin bubbly layers (ice type C; Fig. 4c).

The lower core $(766-1450 \mathrm{~cm})$ was mainly composed of icebonded gravelly sands with some thin ice layers and lenses (Fig. 4d).

Among the 58 vertical thin sections cut in the ice from 400 to 765 $\mathrm{cm}$, the pattern of crystal size determined by both DM and L methods was roughly the same and showed a clear inverse correlation between crystal size and sediment concentration. In fact, in all the sections cut through sediment layers, the smallest mean diameter values and $\mathrm{Lx} / \mathrm{Lz}$ ratios close to unity were obtained (Fig. 5). 

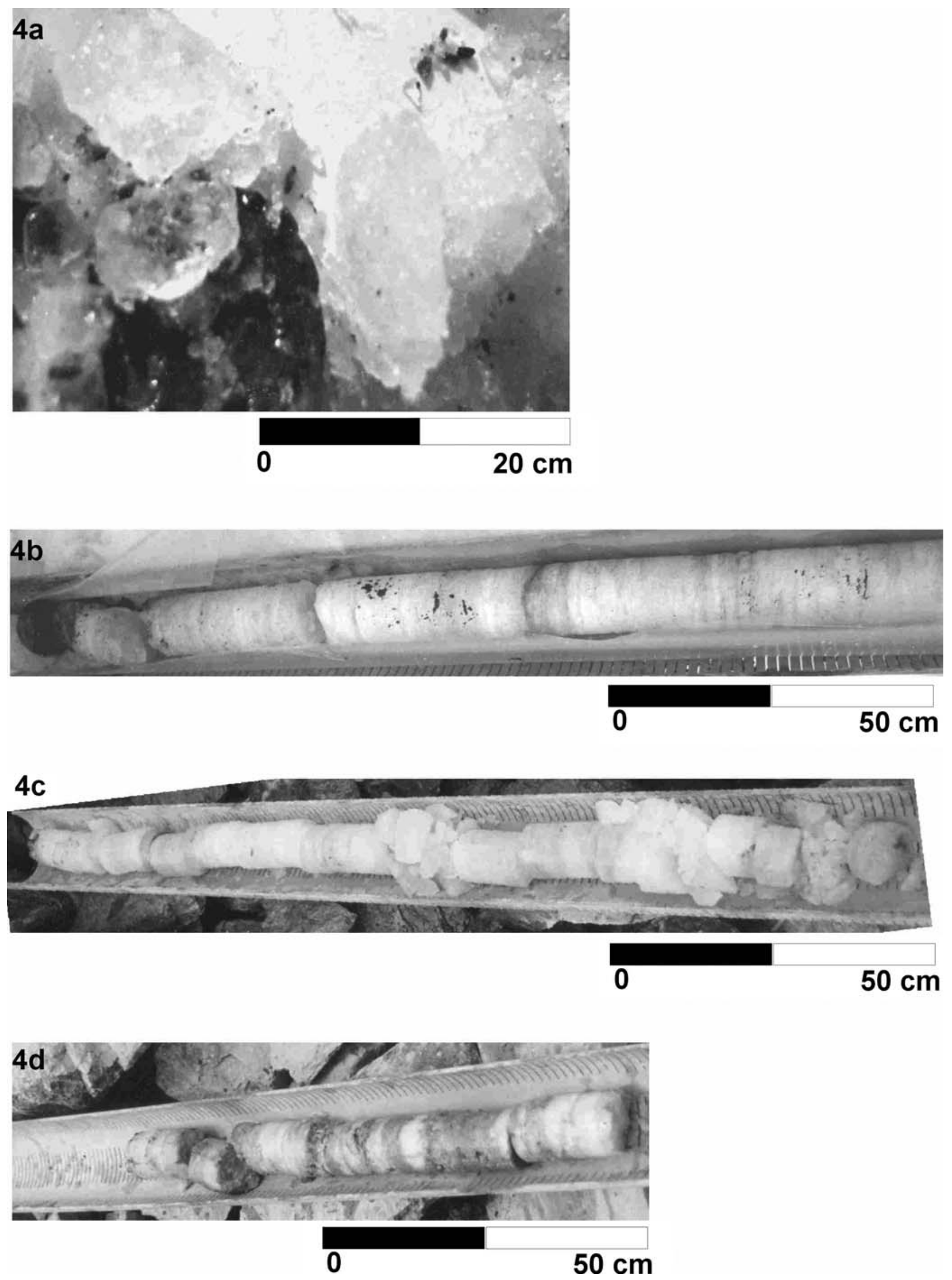

FIGURE 4. (a) ice fragments of the upper part (2.5-4 m); (b) ice core between 4.1 and $5.6 \mathrm{~m}$-note the subhorizontal foliations and debris bands; (c) ice core between 5.6 and $7.1 \mathrm{~m}$; (d) permafrost core with some thin ice layers between 8.9 and $10 \mathrm{~m}$. The top is always to the left. 


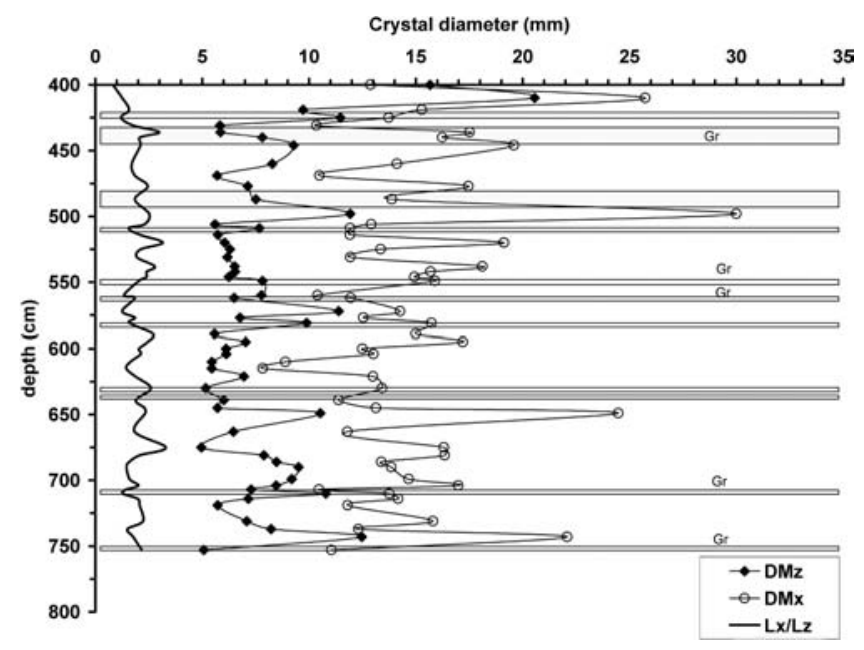

FIGURE 5. Crystal size measured with the linear intercept method on $X$ and $Z$ axes (DMx and DMz) and anisotropy ratio $(L x / L z)$ patterns with depth in the ice body and relationships with the main debris bands.

Crystal size for each section measured by using the $\mathrm{L}$ method ranged from 0.8 to $22 \mathrm{~mm}$ along the vertical plane (Z) and from 1 to 33 $\mathrm{mm}$ along the horizontal plane (X). Crystal size obtained with the DM method ranged from 5 to $21 \mathrm{~mm}$ on the $\mathrm{Z}$ plane and from 7.5 to 30.5 on the $\mathrm{X}$ plane (Fig. 5). In many sections a bimodal distribution in crystal size was noted with large crystals (around $1.5-2 \mathrm{~cm}$ in diameter) on the one hand and very fine crystals $(0.2-1 \mathrm{~mm})$ on the other.

The ratios between the mean linear intercepts in the horizontal $(\mathrm{X})$ and vertical (Z) directions, $\mathrm{Lx} / \mathrm{Lz}$, were also calculated on each vertical section (Gay and Weiss, 1999). This ratio ranged from 1.22 to 3.30 and was above unity for the entire length of the core, except for the thin sections closest to the surface that showed a ratio value of 0.88 , indicating a general horizontal elongation of the crystals (Fig. 5).

The Schmidt plots indicated that most sections had a randomly oriented crystallization and, subordinately, thin sections with a crystal distribution along subhorizontal bands (Fig. 6a, b, c). In most cases Caxes had a mean dip ranging from $9^{\circ}$ to $36^{\circ}$, but some sections showed a mean dip of around $60^{\circ}$, especially where more sediment was present.

Bubble distribution was variable both with tubular bubbles (maximum diameter $3 \mathrm{~mm}$ ) and spherical ones (maximum diameter $1.5 \mathrm{~mm}$ ), the bubble density being generally low, with maximum values in the upper core and in the lower part of the middle core.

Size and shape of the crystals, most of which are elongated in the horizontal plane, and the random distribution of the C-axes are consistent with the characteristics of firn ice (Koerner, 1968; Paterson, 1994). If the alternating of parallel thin layers of fine equigranular crystals and large elongated crystals and the stretching of the bubbles along the subhorizontal plane are considered, it can be argued that this ice was deformed by shearing, as happens at the base of an alpine glacier. The $\mathrm{C}$-axes of Foscagno massive ice core always dip more than the actual surface slope $\left(\sim 5^{\circ}\right)$ at the borehole site, whereas the sediment layers (mainly silty sand, sometimes with gravels) are always subhorizontal and do not show any evidence of postdepositional deformation.

Crystallographically, the Foscagno massive ice is clearly different from that present in the Murtel-Corvatsch rock glacier described by Wagner (1990). In the latter case, ice crystal size is much smaller, Caxes have a dip close to the actual surface slope $\left(10^{\circ}\right)$, and bubbles are randomly oriented. In fact, Wagner considered the ice body of the Murtel-Corvatsch rock glacier as ground ice within permafrost, probably derived by metamorphism of a snow avalanche.
The Foscagno massive ice, on the contrary, seems to be similar to the Galena rock glacier, which Clark et al. (1996) attributed to a relict glacier ice body. The lower core in the Galena rock glacier is characterized by the occurrence of thin silty-sand layers alternating with clear bubbles rich in ice that seem similar to the ice type B of the Foscagno massive ice core.

\section{CHEMICAL ANALYSES}

The chemical data (Table 1) show that the ice core can be clearly divided into 3 main parts, from 230 to $370 \mathrm{~cm}$, from 400 to $746 \mathrm{~cm}$, and the lower portion down to $1450 \mathrm{~cm}$. The only anomalous sample was the one collected at $755 \mathrm{~cm}$.

These data indicate that the upper core $(230-370 \mathrm{~cm})$ has an ionic content (except for calcium and nitrate) similar to that measured in the lower core $(842-1450 \mathrm{~cm}$ ) (Fig. 3). This fact could be attributed to the ice exchange with water, which percolates from the surface, or circulating groundwaters, which are enriched in calcium and other crustal compounds from surrounding ground or debris. The occurrence of calcite and apatite within the more widespread rocks of Foscagno Valley can explain the abundance of calcium (Guglielmin and Notarpietro, 1992). A similar process has been described in the Murtel-Corvatsch ice core, where high calcium levels (up to $600 \mu \mathrm{eq}$ $\mathrm{L}^{-1}$ ) have also been measured (Baltensperger et al., 1990). These high concentrations have been attributed to carbonate dissolution from rocks during percolation of snow meltwater in the ground before refreezing into the still cold active layer during spring (Haeberli et al., 1999).

The middle core (from 400 to $746 \mathrm{~cm}$ ) has lower ionic concentrations, except for nitrate, and could be attributed to ice that has not been subjected to chemical exchange with enriched groundwaters. The only exception was the sample collected at $755 \mathrm{~cm}$, which, for many ions, has concentration levels comparable to those measured in the lower core and can be considered a boundary layer between the middle and lower ice cores.

Some information about ice origin can be inferred from the analysis of the main ionic profiles of the middle core. The plot of sulfate concentrations with respect to ice core depth (Fig. 7a) shows a possible seasonal profile. The seasonal cycles seem to be most evident in the section of the core between 560 and $746 \mathrm{~cm}$, with four distinct summer peaks and an ice thickness of roughly $40-45 \mathrm{~cm}$ for each year. This value represents a minimum estimate for the original ice-equivalent annual layer thickness and is twice the annual stratigraphy in the Galena Creek ice core estimated from the average distance between debris layers (Steig et al., 1998). As shown in Figure 7, maxima in chemical concentrations are not always correlated with debris layers in the Foscagno ice core, unlike what was reported in the Galena Creek ice core (Steig et al., 1998). In the Foscagno ice core, debris layers are not evenly spaced or uniform in composition. For example, the sediment richest in organic matter corresponds to the highest peak of ammonium at $552 \mathrm{~cm}$.

The interpretation of nitrate data is more difficult. In the first part of the middle core $(400-560 \mathrm{~cm})$, mean nitrate concentration was slightly higher than in the following part (560-746 cm) (Fig. 7b), which had concentration levels similar to those measured in the lower core (842$1450 \mathrm{~cm}$ ). This fact can be attributed to diffusion of nitric acid in the ice core, as reported in the literature (Yang et al., 1995; Sommerfeld et al., 1998). This process hindered a clear seasonal signal for nitrate.

The hypothesis of the presence of a preserved annual stratigraphy

FIGURE 6. Pictures of thin sections of ice and corresponding Schmidt diagrams at different depths. (a) ice type a (cf. the text) at $4 \mathrm{~m}$ depth; (b) ice type $b$ at $5.1 \mathrm{~m}$ depth; (c) ice type $c$ at $5.7 \mathrm{~m}$ depth. 

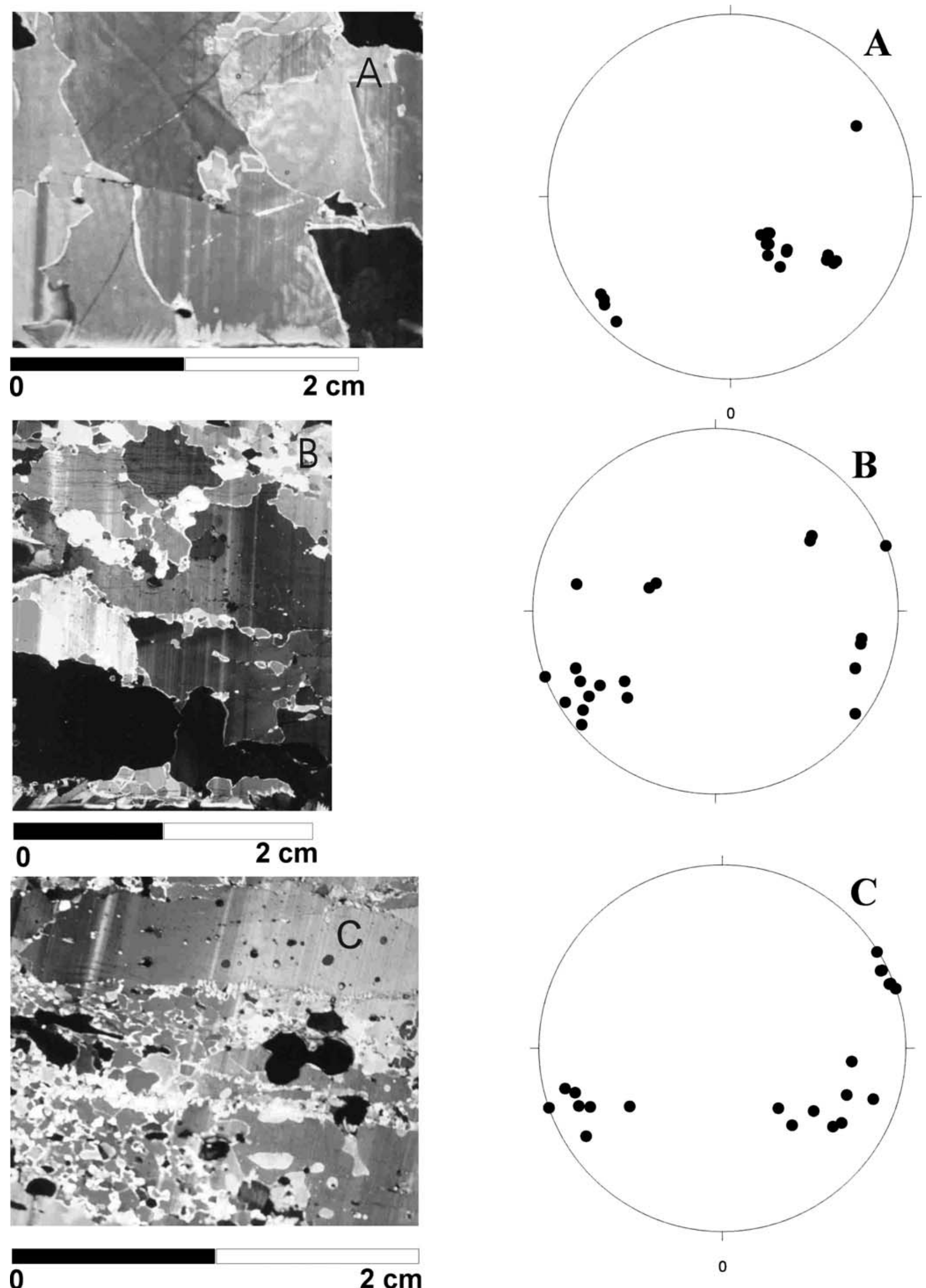

M. Guglielmin ET AL. / 113 
TABLE 1

Arithmetic mean of ion concentrations (expressed in $m e q L^{-1}$ ) of the different ice core layers; in parentheses one standard deviation is reported; $\mathrm{N}$ is number of samples

\begin{tabular}{|c|c|c|c|c|c|c|c|c|c|c|c|}
\hline Depth $(\mathrm{cm})$ & $\mathrm{N}$ & $\mathrm{Cl}^{-}$ & $\mathrm{NO}_{3}^{-}$ & $\mathrm{SO}_{4}{ }^{2-}$ & $\mathrm{Na}^{+}$ & $\mathrm{NH}_{4}^{+}$ & $\mathrm{K}^{+}$ & $\mathrm{Mg}^{2+}$ & $\mathrm{Ca}^{2+}$ & $\begin{array}{c}\text { nss } \\
\text { SO4 (Na) }\end{array}$ & $\begin{array}{c}\text { Total ion } \\
\text { content }\end{array}$ \\
\hline $230-370$ & 6 & $\begin{array}{c}14.6 \\
(10.1)\end{array}$ & $\begin{array}{c}3.3 \\
(1.1)\end{array}$ & $\begin{array}{c}58.0 \\
(38.4)\end{array}$ & $\begin{array}{l}32.4 \\
(8.9)\end{array}$ & $\begin{array}{c}7.2 \\
(2.4)\end{array}$ & $\begin{array}{c}64.7 \\
(62.8)\end{array}$ & $\begin{array}{c}28.9 \\
(13.9)\end{array}$ & $\begin{array}{c}608.6 \\
(450.0)\end{array}$ & $\begin{array}{c}54.1 \\
(38.2)\end{array}$ & $\begin{array}{c}817.8 \\
(535.1)\end{array}$ \\
\hline $400-746$ & 44 & $\begin{array}{c}3.9 \\
(3.6)\end{array}$ & $\begin{array}{c}1.9 \\
(1.4)\end{array}$ & $\begin{array}{c}3.5 \\
(2.3)\end{array}$ & $\begin{array}{c}7.9 \\
(5.9)\end{array}$ & $\begin{array}{c}3.5 \\
(3.2)\end{array}$ & $\begin{array}{c}4.3 \\
(2.4)\end{array}$ & $\begin{array}{c}5.7 \\
(3.1)\end{array}$ & $\begin{array}{c}31.0 \\
(17.1)\end{array}$ & $\begin{array}{c}2.5 \\
(2.1)\end{array}$ & $\begin{array}{c}61.6 \\
(25.3)\end{array}$ \\
\hline 755 & 1 & 44.8 & 2.4 & 14.2 & 80.8 & 17.2 & 17.2 & 42.0 & 84.4 & 4.4 & 302.9 \\
\hline $842-1450$ & 20 & $\begin{array}{c}9.9 \\
(5.5)\end{array}$ & $\begin{array}{c}0.8 \\
(0.6)\end{array}$ & $\begin{array}{c}43.2 \\
(33.6)\end{array}$ & $\begin{array}{c}56.5 \\
(37.2)\end{array}$ & n.d. & $\begin{array}{c}48.3 \\
(29.8)\end{array}$ & $\begin{array}{c}43.7 \\
(27.8)\end{array}$ & $\begin{array}{l}122.2 \\
(89.7)\end{array}$ & $\begin{array}{c}36.3 \\
(30.1)\end{array}$ & $\begin{array}{c}324.7 \\
(202.7)\end{array}$ \\
\hline
\end{tabular}

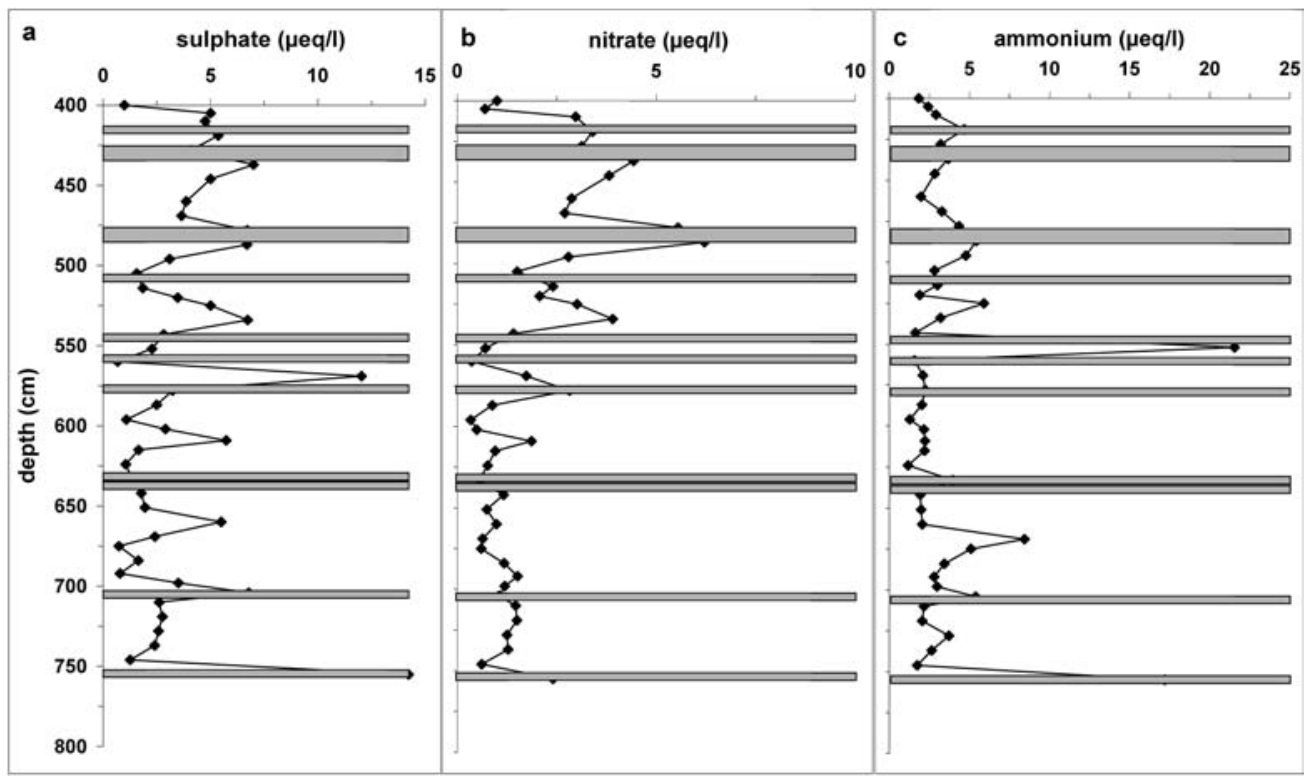

FIGURE 7. Depth profile of selected ions: (a) sulfate; (b) nitrate; (c) ammonium (expressed as $\mu$ eq $L^{-1}$ ) with superimposed debris layers. in the middle core suggests that the ice originated from snow firnification and was not affected by strong postdepositional effects. This hypothesis is also strengthened by considering the correlation between sodium and chloride in the ice samples. In the Foscagno ice core, in fact, a very good correlation is found between sodium and chloride $\left(\mathrm{R}^{2}>0.95\right)$ (Fig. 8). Generally these chemical species have been found to be highly correlated with one another in rain in Valtellina, Central Alps (Balestrini et al., 2000), and in snow in the Western Alps (Maupetit and Delmas, 1994). This correlation is often preserved in firn from cold glaciers, as observed by Maupetit et al. (1995). Furthermore, the average $\mathrm{Na} / \mathrm{Cl}$ ratio (1.7) is only slightly higher than that (1.05) measured in a 5-yr wet deposition monitoring program in Val Masino, a side valley of the Valtellina (Balestrini et al., 2000). By contrast, the correlation between sodium and chloride is poor $\left(\mathrm{R}^{2}<0.40\right)$ in the upper and lower cores, from 230 to $370 \mathrm{~cm}$ and from 842 to $1450 \mathrm{~cm}$, respectively, where the high $\mathrm{Na} / \mathrm{Cl}$ ratios (respectively 3.1 and 6.5) indicate a strong sodium contribution from the soil.

The preservation of seasonal trends was possible because the Foscagno ice core was not subjected to percolation processes during summer months. A comparison with anion concentrations in an ice core from a medium-altitude temperate glacier (Calderone glacier, Central Italy), where an evident summer percolation has been detected, shows indeed that in the Calderone glacier the extensive percolation led to very low concentrations of nitrate and sulfate, four to five times lower than those measured in the Foscagno rock glacier, and no seasonal trend could be demonstrated (Polesello, personal communication).
Since exchange of ice with ion enriched groundwater and percolation phenomena in the ice core can be excluded, the ionic content of Foscagno ice can be considered representative of the original deposition and can be compared with ice measured in high-altitude alpine ice cores. The average concentrations of sulfate and nitrate are indeed comparable to those typical of a preindustrial era but are two to five times lower than those measured in the last-century ice layers in alpine cold glaciers (Table 2).

\section{ICE AGE}

The maximum extent of the Little Ice Age in the Foscagno Valley did not leave any clear geomorphological evidence, but, according to Guglielmin et al. (2001), ice reached only $2650 \mathrm{~m}$ a.s.l., far from the borehole location ( $2500 \mathrm{~m}$ a.s.1.). The LIA advance induced a marked permafrost degradation, as testified by the fact that, above $2650-2700 \mathrm{~m}$ a.s.l., permafrost distribution is much more patchy and the active layer is much thicker than around the borehole. Moreover, two paleosoils buried by the active and inactive parts of Foscagno rock glacier were respectively dated with ${ }^{14} \mathrm{C}$ at $2,200 \pm 60 \mathrm{yr}$ and 2,700 $\pm 70 \mathrm{yr}$ B.P. (Calderoni et al., 1998). These uncalibrated ages correspond to ranges in the calibrated calendar age of 375-165 B.C. and 395-60 B.C. for the active part and 905-805 B.C. and 1000-790 B.C. at statistical probabilities of $68 \%$ and $95 \%$, respectively. These ages imply that the glacier ice is younger than $2200 \mathrm{yr}$ B.P. (or 395-60 B.C.), although considering the cristallographical characteristics of the ice that indicate 


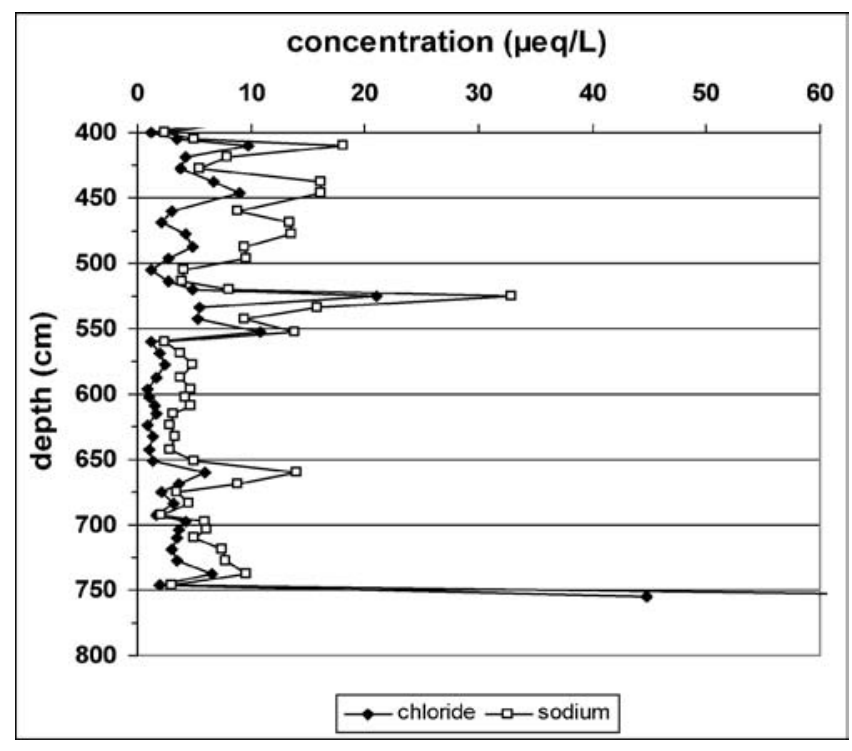

FIGURE 8. Depth profile of the concentrations of $\mathrm{Na}^{+}$and $\mathrm{Cl}^{-}$ (expressed as $\mu$ eq $L^{-1}$ ).

a probable origin at higher altitude in the cirque and then a downvalley flow, we cannot exclude the possibility that it is older. In addition, considering the palynological investigations carried out in this area (Burga, 1987; Scolari, 1996) and taking into account the dated glacier advances in the Upper Valtellina (Orombelli and Pelfini, 1985; Baroni and Orombelli, 1996), the coldest and wettest period documented during the Holocene occurred at 3000-3300 yr B.P. It is probable that the ice and the overlying till date from this period. It is still not possible to rule out an older age, in connection with the cold phases at the beginning of the Holocene, although this conclusion is not compatible with the known geomorphologic evolution of the valley.

The proposed age of the rock glacier is consistent with the chemical composition of the main part of the Foscagno ice, whose ionic concentrations are two to five times lower than those measured in ice layers from the last century (Table 2). Furthermore, we can observe that nitrate, sulfate, and ammonium concentrations are of the same order of magnitude as those measured in Murtel-Corvatsch rock glacier (Baltensperger et al., 1990), which was dated $2250 \pm 100$ years B.P. (uncalibrated radiocarbon age; Haeberli et al., 1999).

\section{Conclusion}

Comparison with other studied rock glaciers (Murtel I and Galena Creek) indicates that the ice body from the Foscagno rock glacier between $4 \mathrm{~m}$ and $7.65 \mathrm{~m}$ depth is glacier ice. Between 2.5 and $4 \mathrm{~m}$, however, ice characteristics are consistent with superimposed ice that formed as a consequence of melting and refreezing processes.

The presence of seasonality in the sulfate profile connected to sediment layers and the strong correlation between sodium and chloride in the middle core $(400-746 \mathrm{~cm})$ suggest an absence of melting and refreezing processes and are consistent with deposited snow transformed into firn under cold conditions, as happens in high-altitude cold glaciers. In contrast, the upper core between 230 and $370 \mathrm{~cm}$ depth was subjected to melting and freezing cycles that led to an exchange of salts, especially calcium, with circulating groundwater.

On the basis of the chemical and textural characteristics of the ice, the massive ice of the Foscagno rock glacier can be considered as a body of glacier ice. In addition, considering its microstructural characteristics, it is reasonable to say that this ice was formed somewhere in the upper part of the cirque and flowed down to its actual position. We believe that this massive ice is a relict of glacier ice preserved within a permafrost body because, from the available geophysical investigations, the massive ice should be limited in extent to not more than $10 \%$ of the total area of the rock glacier, mainly in the frontal part of the active rock glacier, and with a thickness not exceeding 10-12 m. Moreover, the more widespread occurrence of permafrost within the rock glacier and its occurrence also beneath the cored massive ice core (between 7.65 and $14.5 \mathrm{~m}$ ), characterized by an alternation of ice-bonded sediments, suggest that the Foscagno rock glacier is the result of a complex history in which different types of ice are preserved. The determination of the age of the relict glacier ice core needs further research on the creep velocity of the rock glacier and possibly the absolute datation of the organic mat within new ice cores. Nevertheless, the occurrence of a relict glacier ice core in which the seasonal geochemical stratigraphy is preserved makes the Foscagno rock glacier a potential paleoclimate archive that with further investigation (such as isotopic or palynological analyses) could provide useful information about the Holocene climatic evolution of the Alps.

\section{Acknowledgments}

We are very grateful to M. Teruzzi (University of Milan) for his assistance in sample preparation and analysis. This work was supported by the E.U. PACE project (contract ENV4-CT-0492) and by INRM (Istituto Nazionale di Ricerca della Montagna). Special thanks are due to Prof. R. Souchez and Prof. G. Orombelli for comments and suggestions. We also wish to thank the two anonymous referees who significantly improved the work with their suggestions.

\section{References Cited}

Balestrini, R., Galli, L., and Tartari, G., 2000: Wet and dry deposition at prealpine and alpine sites in northern Italy. Atmospheric Environment, 34: 1455-1470.

Baltensperger, U., Gäggeler, H., Gloor, M., Hoehn, E., and Keil, R.,

TABLE 2

Comparison of nitrate and sulfate data measured in different types of Italian and Swiss glaciers and rock glaciers

\begin{tabular}{|c|c|c|c|c|c|c|}
\hline Site & Type & $\begin{array}{l}\text { Altitude } \\
\text { (m a.s.l.) }\end{array}$ & $\begin{array}{c}\text { Date or } \\
\text { depth }(\mathrm{cm})\end{array}$ & $\begin{array}{l}\mathrm{NO}_{3}^{-} \\
\mu e q \mathrm{~L}^{-1}\end{array}$ & $\begin{array}{l}\mathrm{SO}_{4}{ }^{2-} \\
\mu e q \mathrm{~L}^{-1}\end{array}$ & Reference \\
\hline Foscagno (Valtellina, Central Alps) & Rock glacier & 2510 & $400-746 \mathrm{~cm}$ & $1.9 \pm 1.4$ & $3.5 \pm 2.3$ & This work \\
\hline Calderone (Gran Sasso, Apennines) & Temperate glacier & 2867 & $6-196 \mathrm{~cm}$ & $0.64 \pm 0.60$ & $0.66 \pm 0.44$ & Polesello et al., unpublished results \\
\hline \multirow{5}{*}{ Colle Gnifetti (Monte Rosa, Western Alps) } & Cold glacier & 4450 & 1890-1910 A.D. & $0.96 \pm 0.3$ & $2.3 \pm 0.9$ & Wagenbach et al., 1988 \\
\hline & & & 1850-1880 A.D. & $1.3 \pm 0.1$ & $2.1 \pm 0.2$ & Döscher et al., 1995 \\
\hline & & & 1970-1986 A.D. & $4.5 \pm 1.8$ & $10 \pm 5$ & Wagenbach et al., 1988 \\
\hline & & & 1965-1981 A.D. & $3.5 \pm 0.3$ & $14.4 \pm 1.3$ & Döscher et al., 1995 \\
\hline & & 4480 & 1973-1995 A.D. & $7.2 \pm 5.6$ & $23 \pm 20$ & Casati, 1998 \\
\hline Colle Lys (Monte Rosa, Western Alps) & Cold glacier & 4240 & 1970-1995 A.D. & $4.8 \pm 4.4$ & $11.8 \pm 12.6$ & Casati, 1998 \\
\hline
\end{tabular}


1990: Chemical composition. In Haeberli, W. (ed.), Pilot Analyses of Permafrost Cores from the Active Rock Glacier Murtel I, Piz Corvatsch, Eastern Swiss Alps: A Workshop Report. WAW-ETH Zürich, 24-26.

Baroni, C., and Orombelli, G., 1996: The alpine "iceman" and Holocene climatic change. Quaternary Research, 46: 78-83.

Barsch, D., 1987: The problem of the ice-cored rock glacier. In Giardino, J. R., Shroder, J. F., and Vitek, J. D. (eds.), Rock Glaciers. London: Allen and Unwin, 45-53.

Brown, W. H., 1925: A probable fossil glacier. Journal of Geology, 33: 464-466.

Burga, C. A. 1987: Gletscher und vegetationsgeschicte der Südrätischen Alpen seit der Späteiszeit Puschlav, Livigno, Bormiese. Basel: Birkèauser Verlag, 101. 162 pp.

Calderoni, G., Guglielmin, M., Lozej, A., and Tellini, C., 1993: Researches on rock glaciers in the Italian Central Alps, Valtellina, Sondrio, Italia. Proceedings 6th International Conference on Permafrost. Beijing, Vol. 1, 72-77.

Calderoni, G., Guglielmin, M., and Tellini, C., 1998: Radiocarbon dating and postglacial evolution, Upper Valtellina and Livignese area, Sondrio, Central Italian Alps. Permafrost Periglacial Processes, 9: 275-284.

Casati, P., 1998: Ricostruzione climatico-ambientale dgli ultimi decenni mediante l'analisi della carota di ghiaccio del Colle del Lys e applicazione di modelli per la definizione delle sorgenti atmosferiche. Thesis, University of Milano. XX pp.

Clark, D. H., Steig, E. J., Potter, N. J., Fitzpatrick, J., Updike, A. B., and Clark, G. M., 1996: Old ice in rock glaciers may provide longterm climate records. EOS, Transactions, American Geophysical Union, 77: 217-222.

Döscher, A., Gäggeler, H. W., Schotterer, U., and Schwikowski, M., 1995: A 130 years deposition record of sulfate, nitrate and chloride from a high-alpine glacier. Water Air Soil Pollution, 85: 603609.

Gay, M., and Weiss, J., 1999: Automatic reconstruction of polycrystalline ice microstructure from image analysis: application to the Epica ice core at Dome Concordia, Antarctica. Journal of Glaciology, 45(151): 547-554.

Guglielmin, M., 1989: I rock glacier del Passo del Foscagno (Alta Valtellina, Sondrio). Natura Bresciana, 26: 35-47.

Guglielmin, M., 1997: Il Permafrost Alpino. Quaderni Geodinamica Alpina e Quaternaria, 5. 113 pp.

Guglielmin, M., and Notarpietro, A., 1992. Il granito del Monte Forcellina. Miner. Petrogr. Acta, 35: 257-264

Guglielmin, M., and Tellini, C., 1994: Rilevamento del permafrost con il metodo BTS-bottom temperature of the winter snow cover: nell'alta Valtellina Sondrio, Italia. Geografia Fisica Dinamica Quaternaria, 17: 47-54

Guglielmin, M., Lozej, A., and Tellini, C., 1994: Permafrost distribution and rock glaciers in the Livigno Area, Northern Italy. Permafrost Periglacial Processes, 5: 1-12.

Guglielmin, M., Cannone, N., and Dramis, F., 2001: Permafrost-glacial evolution during the Holocene in the Italian Central Alps. Permafrost Periglacial Processes, 12: 111-124.

Haeberli, W., 1985: Creep of mountain permafrost. Internal Structure and Flow of Alpine Rock Glaciers. Zurich: E.T.H.: 142 pp.

Haeberli, W., Huder, J., Keusen, H. R., Pika, J., and Rothlisberger, H., 1988: Core drilling through rock glacier-permafrost. Proceedings 5th International Conference on Permafrost: Trondheim, 5(2): 937942.

Haeberli, W., Kaab, A., Wagner, S., Vonder Mühll, D., Geissler, P.,
Haas, J. N., Glatzel-Mattheier, H., and Wagenbach, D., 1999: Pollen analysis and ${ }^{14} \mathrm{C}$ age of moss remains in a permafrost core recovered from the active rock glacier Murtel-Corvatsch, Swiss Alps: geomorphological and glaciological implications. Journal of Glaciology, 45(149): 1-8.

Hauck, C., Guglielmin, M., Isaksen, K., and Vonder Mühll, D., 2001: Applicability of frequency- and time-domain electromagnetic methods for mountain permafrost studies. Permafrost and Periglacial Processes, 12: 39-52.

Koerner, R. M., 1968: Fabric analysis of a core from the Meighen Ice Cap, Northwest Territories, Canada. Journal of Glaciology, 7(51): 421-430.

Langway, C. C., Jr., 1958: Ice fabrics and the universal stage. U.S. Army Snow Ice and Permafrost Research Establishment, Technical Report No. 62.

Maupetit, F., and Delmas, R. J., 1994: Snow chemistry of high altitude glaciers in the French Alps. Tellus, 46B: 304-324.

Maupetit, F., Wagenbach, D., Weddeling, P., and Delmas, R. J., 1995: Seasonal fluxes of major ions to a high altitude cold alpine glacier. Atmospheric Environment, 29: 1-9.

Orombelli, G., and Pelfini, M., 1985: Una fase di avanzata glaciale nell'Olocene superiore, precedente alla Piccola Glaciazione, nelle Alpi Centrali. Rendiconti Società Geologica Italiana, 8: 17-20.

Paterson, W. S. B., 1994: The Physics of Glaciers, 3rd ed. New York: Pergamon Press. 480 pp.

Potter, N., Jr., 1972: Ice-cored rock glacier, Galena Creek, northern Absaroka Mountains, Wyoming. Geological Society of America Bulletin, 83: 3025-3058.

Scolari, F., 1996: Indagini floristiche e paleobotaniche nella Vallaccia del Foscagno Alpi Centrali, Bormio-Sondrio. Unpublished thesis, Parma University. 58 pp.

Sommerfeld, R. A., Knight, C. A., and Kay Laird, S., 1998: Diffusion of $\mathrm{HNO}_{3}$ in ice. Geophysical Research Letters, 25: 935-938.

Steig, E. J., Fitzpatrick, J., Potter, N. J., and Clark, D. H., 1998: The geochemical record in rock glaciers. Geografiska Annaler, 80: 277-286.

Teruzzi, M., 2000: Analisi chimiche e fisiche di ground ice nell'ambiente periglaciale polare e alpino. esempi da Amorphous Glacier Antartide: Foscagno Sondrio: e Pietraporzio Cuneo. Unpublished thesis, University of Milan. XX pp.

Thorsteinsson, Th., Kipfstuhl, J., Eicken, H., Johnsen, S. J., and Fuhrer, K., 1995: Crystal size variations in Eemian-age ice from the GRIP ice core, central Greenland. Earth Planetary Science Letters, 1313-4: 381-394.

Wagenbach, D., Munnich, K. O., Schotterer, U., and Oeschger, H., 1988: The anthropogenic impact on snow chemistry at Colle Gnifetti, Swiss Alps. Annals of Glaciology, 10: 183-187.

Wagner, S., 1990: Ice fabric and air bubbles. In Haeberli, W. (ed.), Pilot Analyses of Permafrost Cores from the Active Rock Glacier Murtel I, Piz Corvatsch, Eastern Swiss Alps: A Workshop Report. Zürich: WAW-ETH, 16-22.

Whalley, W. B., 1974: Rock glaciers and their formation as a part of a glacier debris-transport system. Geographic Papers, Reading University. $24 \mathrm{pp}$.

Yang, Q., Mayewski, P. A., Whitlow, S., Twickler, M., Morrison, M., Talbot, R., Dibb, J., and Linder, E., 1995: Global perspective of nitrate flux in ice cores. Journal of Geophysical Research, 100(D3): $5113-5121$.

Ms submitted July 2002 Revised ms submitted May 2003 